\title{
DINAMIKA BUDAYA SEKOLAH TERHADAP PENDEKATAN METAKOGNITIF DALAM PROSES PEMBELAJARAN UNTUK MENINGKATKAN KEMAMPUAN HIGH ORDER THINKING SKILLS
}

\author{
Oleh: \\ Itgo Hatchi ${ }^{1)}$; Dwi Aninditya Siregar ${ }^{2)}$; Lia Purnama Sari ${ }^{3)}$; Suryadi Fajri ${ }^{4)}$ \\ ${ }^{1,2,3}$ Dosen Institut Pendidikan Tapanuli Selatan \\ 1'hatchiitgo@gmail.com \\ 22wi.aninditya@gmail.com \\ ${ }^{3}$ liasari2808@gmail.com \\ ${ }^{4}$ Dosen Universitas Islam Negeri Imam Bonjol Padang \\ ${ }^{4}$ suryadifajri14@yahoo.co.id
}

\begin{abstract}
Abstrak
Penelitian ini bertujuan untuk mengetahui gambaran dinamika budaya sekolah di MAN 2 Padangsidimpuan dalam proses pembelajaran. Metode penelitian yang digunakan dalam penelitian ini adalah kualitatif dengan jenis penelitian yang dilakukan adalah penelitian lapangan (field research). Populasi dalam penelitian ini adalah seluruh siswa di MAN 2 Padangsidimpuan, sedangkan untuk sampelnya adalah siswa kelas XI MIA 2. Hasil analisis data setelah penelitian didapatkan data observasi bahwa siswa di MAN 2 Padangsidimpuan memiliki dua kompetensi budaya sikap yaitu budaya spiritual dan budaya sosial. Pada kriteria budaya spiritual ini ada sepuluh aspek budaya sikap yang diamati. Didapatkah bahwa sembilan dari sepuluh budaya spiritual telah dimiliki oleh siswa MAN 2 Padangsidimpuan. Aspek yang tidak dimiliki yaitu menghargai perbedaan agama karena seluruh siswa di MAN 2 Padangsidimpuan beragama Islam. Untuk budaya sosial ada 4 aspek yang diamati dengan masing-masing kriterianya. Ternyata kriteria yang belum dimiliki oleh siswa MAN 2 Padangsidimpuan yaitu pada aspek nasinalisme rela berkorban. Jadi, secara umum dapat ditarik kesimpulan bahwa siswa MAN 2 Padangsidimpuan telah memiliki dinamiki budaya sekolah yang bagus.
\end{abstract}

Kata kunci: Budaya sekolah, Pendekatan Metakognitif, High Order Thinking Skills

\section{PENDAHULUAN}

Dalam kehidupan bermasyarakat tidak bisa terlepas dari ikatan budaya yang ada di daerah tersebut. Ikatan budaya ini telah tercipta sejak lama yang merupakan kebiasaan dari masyarakat yang bersangkutan. Adanya suatu buadaya akan memberikan perbedaan antara masyarakat yang satu dengan yang lainnya terutama dalam melakukan interaksi dan bertindak untuk menyelasaikan suatu persoalan yang ada. Budaya yang telah tercipta tersebut dapat memberikan manfaat bagi kegiatan kelompok masyarakat tersebut. Budaya ini dapat diartikan sebagai sesuatu hal yang luas menurut Schein (1996) budaya organisasi adalah pola dasar yang diterima oleh organisasi untuk bertindak dan memecahkan masalah, membentuk masyarakat yang mampu beradaptasi dengan lingkungan dan mempersatukan anggota.

Kebudayaan juga idefenisikan sebagai keseluruhan sistem gagasan, tindakan dan hasil karya manusia dalam rangka kehidupan masyarakat yang dijadikan milik diri manusia dalam rangka kehidupan masyarakat yang dijadikan milik diri manusia dengan cara belajar (Koentjaraningrat, 2003:72). Suatu budaya bisa berasal dari keluarga, sosial, lingkungan, adat istiadat serta budaya sekolah. Budaya sekolah dapat diartikan beragam oleh beberapa ahli. Short dan Greer mendefenisikan bahwa budaya sekolah adalah suatu keyakinan, norma serta kebiasaan yang terdapat di dalam sekolah yang bias dibentuk, diperkuat serta dipelihara melalui guru-guru di lingkungan sekolah tersebut. Suatu budaya sekolah akan melahirkan budaya belajar bagi siswa yang nanti nya akan berkaitan dengan prestasi hasil belajar karena dalam budaya sekolah tersebut telah tergambar kebiasan belajar serta cara-cara dan teknik belajar yang telah dianut oleh siswa di dalam sekolah tersebut. Jika suatu sekolah telah memiliki budaya belajar yang baik maka akan meberikan dampak yang baik pula bagi prestasi belajar siswa di sekolah tersebut.

MAN 2 Padangsidimpuan sebagai salah satu sekolah yang berbudaya di lingkungan dikota Padangsidimpuan. Sekolah ini terkenal dengan budaya kedisiplinan terhadap waktu. Sehingga kedisiplinan waktu ini dijadikan sebagai salah satu karakter dari siswa di MAN 2 Padangsidimpuan. Selain dari pada itu karakter siswa MAN 2 Padangsidimpuan yang religius juga tergambar dari jelas menjadi karakter andalan dari sekolah ini, dimana setiap paginya di sekolah ini selalu dilakukan tausiyah keagamaan, kegiatan tausyiah ini dilakukan oleh siswa sendiri. MAN 2 Padangsidimpuan dijadikan salah satu sekolah unggulan di Kota Padangsidimpuan. Input dari sekolah ini tergolong baik terutama di tingkat kota 
Padangsidimpuan dimana, setiap tahun calon siswa yang mendaftar tiap tahun ajarannya berlimpah sehingga sekolah dapat memilih siswa yang berkualitas untuk diterima sebagai siswanya, namun dalam prestasi akademik seperti lomba olimpiade tingkat provinsi Sumatera Utara, tingkat Nasional atau Internasional. Siswa-siswa sekolah ini belum menunjukkan prestasinya secara maksimal meskipun dari segi peraturan sekolah secara tegas dinyatakan oleh MAN 2 Padangsidimpuan bahwa siswa unggul dalam prestasi dan luas dalam penguasaan IPTEK seperti tertulis dalam visi sekolah tersebut.

Hal ini terjadi karena model pembelajaran di sekolah ini masih konvensional, meskipun sekolah ini telah menggunakan Kurikulum 2013 yang menjadi rujukan proses pembelajaran pada satuan pendidikan, dan merujuk pada Penguatan Pendidikan Karakter (PPK) tetapi belum dilaksakan sebagaimana mestinya. Oleh karena itu perlu adanya peningkatan pengetahuan mengenai High Order Thinking Skills (HOTS) disekolah ini karena dengan HOTS diharapakan siswa dapat mencapai berbagai kompetensi dengan penerapan HOTS atau Keterampilan Bepikir Tingkat Tinggi. Kompetensi tersebut yaitu berpikir kritis (criticial thinking), kreatif dan inovasi (creative and innovative), kemampuan berkomunikasi (communication skill), kemampuan bekerja sama (collaboration) dan kepercayaan diri (confidence). Lima hal tersebut menjadi target karakter siswa untuk sistem evaluasi dalam ujian nasional dan merupakan kecakapan abad 21 yang diharapkan oleh pemerintah di dunia pendidikan.

\section{METODE PENELITIAN}

Jenis penelitian yang dilakukan adalah penelitian lapangan (field research). Jenis penelitian ini merupakan penelitian dengan menggunakan informasi yang diperoleh dari sasaran atau objek penelitian yang disebut informan atau responden melalui instrumen pengumpulan data seperti wawancara, observasi dan dokumentasi. Penelitian ini termasuk penelitian kualitatif jika ditinjau dari segi datanya. Pengambilan tempat penelitian ini dilakukan secara purposive, artinya penentuan lokasi dilakukan dengan sengaja karena peneliti telah mengetahui keadaan dan lokasi serta adanya korelasi dengan permasalahan dalam penelitian. Teknik purposive ini merupakan penentuan sumber data atau lokasi dengan pertimbangan tertentu. Penelitian ini dilakukan pada MAN 2 Padangsidimpuan sebagai lokasi yang sesuai dengan latar belakang masalah untuk dijadikan sebagai objek penelitian.

\section{HASIL PENELITIAN DAN PEMBAHASAN}

Berdasarkan hasil observasi yang sudah dilakukan di MAN 2 Padangsidimpuan terhadap pendekatan metakognitif dalam proses pembelajaran untuk meningkatkan kemampuan high order thinking skill (HOTS) didapatkan hasil berupa dinamika budaya sekolah yang didasarkan pada konsep budaya sekolah yang disesuaikan dengan HOTS. Hal ini diasumsikan bahwa pada setiap peserta didik memeiliki perilaku yang baik yang dijumpai selama proses pembelajaran. Budaya sekolah yang mengacu pada pendekatan metakognitif dalam proses pembelajar untuk meningkatkan HOTS ini mengacu pada dua aspek kompetensi budaya sikap yaitu: 1) Budaya spiritual dan 2) Budaya sosial. Budaya sekolah untuk kompetensi budaya spiritual ini tergambar pada tabel 1 dibawah ini:

Tabel 1. Budaya sekolah untuk komptensi budaya spiritual

\begin{tabular}{|c|c|c|}
\hline No & $\begin{array}{c}\text { Aspek yang } \\
\text { diamati }\end{array}$ & Sikap siswa \\
\hline 1 & Cinta Damai & $\begin{array}{l}\text { Bersalaman dengan guru dan sesama } \\
\text { siswa saat tiba disekolah }\end{array}$ \\
\hline 2 & Toleransi & $\begin{array}{l}\text { Saling meminjamkan mukena dan } \\
\text { al'quran kepada teman yang tidak } \\
\text { membawanya ke sekolah }\end{array}$ \\
\hline 3 & $\begin{array}{l}\text { Menghargai } \\
\text { perbedaan agama }\end{array}$ & $\begin{array}{l}\text { Karena semua siswa di MAN } 2 \\
\text { Padangsidimpuan beragama islam } \\
\text { sehingga tidak terlihat siswa saling } \\
\text { menghargai perbedaan agama. } \\
\text { Tetapi saling mengharagai agama } \\
\text { dapat terlihat pada saat teman } \\
\text { melakukan puasa senin kamis }\end{array}$ \\
\hline 4 & Teguh Pendirian & $\begin{array}{l}\text { Siswa tidak mau terlambat datang ke } \\
\text { sekolah walaupun cuaca tidak } \\
\text { bersahabat, hal ini dikarenakan siswa } \\
\text { yang terlambat akan diberikan } \\
\text { hukuman berupa hafalan } 3-5 \text { ayat } \\
\text { (tergantung lama keterlambatan) }\end{array}$ \\
\hline 5 & Percaya Diri & $\begin{array}{l}\text { Siswa berani menampilkan diri baik } \\
\text { pada saat upacara bendera dan kuliah } \\
\text { tujuh menit (kultum) }\end{array}$ \\
\hline 6 & Anti kekerasan & $\begin{array}{l}\text { Siswa MAN } 2 \text { Padangsidimpuan } \\
\text { tidak pernah terlibat tawuran antar } \\
\text { sekolah maupun sesama teman di } \\
\text { lingkungan sekolah }\end{array}$ \\
\hline 7 & Persahabatan & $\begin{array}{l}\text { Siswa saling mengenal satu sama } \\
\text { lain walaupun berbeda tingkatan } \\
\text { kelas }\end{array}$ \\
\hline 8 & Ketulusan & $\begin{array}{l}\text { Siswa ikhlas memberikan sedekah } \\
\text { dan infaq setiap minggu }\end{array}$ \\
\hline 9 & $\begin{array}{l}\text { Tidak memaksakan } \\
\text { kehendak }\end{array}$ & 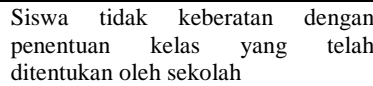 \\
\hline 10 & Membantu sesama & $\begin{array}{l}\text { Siswa selalu menolong teman yang } \\
\text { mengalami kesulitan }\end{array}$ \\
\hline
\end{tabular}

Dari Tabel 1 di atas terlihat bahwa budaya spiritual siswa dalam proses pembelajaran sudah mengarah pada kompetensi budaya sikap yang berorientasi pada HOTS dan dikaitkan dengan Penguatan Pendidikan Karakter (PPK). Sementara itu, untuk budaya sosial dapat dilihat pada Tabel 2 di bawah ini:

Tabel 2. Budaya sekolah untuk komptensi budaya sosial

\begin{tabular}{|c|c|c|}
\hline No & $\begin{array}{l}\text { Kriteria budaya } \\
\text { sosial }\end{array}$ & Sikap siswa \\
\hline $\mathbf{I}$ & \multicolumn{2}{|l|}{ Nasionalisme } \\
\hline & $\begin{array}{l}\text { 1. Apresiasi budaya } \\
\text { bangsa sendiri }\end{array}$ & $\begin{array}{l}\text { Siswa menggunakan pakaian } \\
\text { daerah saat acara-acara tertentu }\end{array}$ \\
\hline & $\begin{array}{l}\text { 2. Menjaga } \\
\text { kekayaan budaya } \\
\text { bangsa }\end{array}$ & $\begin{array}{l}\text { Siswa masih menggunakan bahasa } \\
\text { daerah untuk berinteraksi dengan } \\
\text { sesama teman maupun guru di luar } \\
\text { proses pembelajaran dalam kelas }\end{array}$ \\
\hline & 3. Rela berkorban & $\begin{array}{l}\text { Sikap rela berkorban siswa belum } \\
\text { terlihat di sekolah }\end{array}$ \\
\hline
\end{tabular}




\begin{tabular}{|c|c|c|}
\hline & $\begin{array}{l}\text { 4. Unggul dan } \\
\text { berprestasi }\end{array}$ & $\begin{array}{l}\text { Mengikuti kegiatan olimpiade } \\
\text { tingkat kota Padangsidimpuan } \\
\text { maupun nasional }\end{array}$ \\
\hline & $\begin{array}{l}\text { 5. Menjaga } \\
\text { lingkungan }\end{array}$ & $\begin{array}{l}\text { Siswa selalu membuang sampah } \\
\text { pada tempatnya dan melaksanakan } \\
\text { gotong royong sekali sebulan }\end{array}$ \\
\hline & 6. Taat hukum & $\begin{array}{l}\text { Siswa MAN } 2 \text { selalu menggunakan } \\
\text { helm saat mengendarai sepeda } \\
\text { motor }\end{array}$ \\
\hline & 7. Disiplin & $\begin{array}{l}\text { Siswa selalu berpakaian rapi ke } \\
\text { sekolah dan tidak terlambat datang } \\
\text { ke sekolah }\end{array}$ \\
\hline & $\begin{array}{l}\text { 8. Menghormati } \\
\text { keragaman } \\
\text { budaya dan suku }\end{array}$ & $\begin{array}{l}\text { Siswa selalu saling menghargai } \\
\text { dengan sesama teman, meskipun } \\
\text { berasal dari suku dan budaya yang } \\
\text { berbeda }\end{array}$ \\
\hline II & \multicolumn{2}{|l|}{ Kemandirian } \\
\hline & 1. Kerja keras & $\begin{array}{l}\text { Siswa selalu berusah } \\
\text { menyelesaikan tugas sekolah dan } \\
\text { pekerjaan rumah sebisa mungkin }\end{array}$ \\
\hline & 2. Kreatif & $\begin{array}{l}\text { Siswa mampu mendisain sendiri } \\
\text { kelasnya sehingga suasana belajar } \\
\text { lebih menarik }\end{array}$ \\
\hline & 3. Keberanian & $\begin{array}{l}\text { Siswa berani mengemukakan } \\
\text { pendapat di depan kelas, di } \\
\text { lingkungan sekolah dan berani } \\
\text { tampil di depan kalayak ramai }\end{array}$ \\
\hline III & \multicolumn{2}{|l|}{ Gotong royong } \\
\hline & 1. $\mathrm{Ke}$ & $\begin{array}{l}\text { Siswa bekerja sama dengan teman } \\
\text { baik dalam proses pembelajaran } \\
\text { maupun kegiatan sekolah lainnya }\end{array}$ \\
\hline & $\begin{array}{ll}\text { 2. } & \begin{array}{l}\text { Komitmen atas } \\
\text { keputusan } \\
\text { bersama }\end{array}\end{array}$ & $\begin{array}{l}\text { Siswa melaksanakan setiap } \\
\text { keputusan yang telah diambil } \\
\text { dalam musyawarah misalnya dalam } \\
\text { penegakkan peraturan sekolah }\end{array}$ \\
\hline & $\begin{array}{l}\text { 3. } \begin{array}{l}\text { Musyawarah } \\
\text { mufakat }\end{array}\end{array}$ & $\begin{array}{l}\text { Dalam mengambil keputusan siswa } \\
\text { terlibat secara terbuka, baik rapat } \\
\text { bersama teman maupun bersama } \\
\text { guru dan aparatur sekolah lainnya }\end{array}$ \\
\hline IV & \multicolumn{2}{|l|}{ Integritas } \\
\hline & 1. Anti korupsi & $\begin{array}{l}\text { Siswa tidak mau/bersedia } \\
\text { memberikan uang kepada guru } \\
\text { untuk mendapatkan nilai yang baik }\end{array}$ \\
\hline & $\begin{array}{l}\text { 2. Cinta pada } \\
\text { kebenaran }\end{array}$ & $\begin{array}{l}\text { Siswa masih kurang jujur dalam } \\
\text { berkata baik kepada teman maupun } \\
\text { kepada guru }\end{array}$ \\
\hline & $\begin{array}{l}\text { 3. } \begin{array}{l}\text { Menghargai } \\
\text { martabat } \\
\text { individu }\end{array}\end{array}$ & $\begin{array}{l}\text { Siswa menghargai teman lain yang } \\
\text { memiliki kekurangan sikap }\end{array}$ \\
\hline
\end{tabular}

Dari Tabel 2 di atas terlihat bahwa siswa di MAN 2 Padangsidimpuan memiliki budaya sikap sosial. Hal ini dapat dilihat dari kriteria budaya sosial meliputi aspek nasionalisme, kemandirian, gotong royong dan integritas. Namun, penilaian untuk setiap sikap budaya sosial ini belum pernah dilakukan oleh guru di MAN 2 Padangsidimpuan. Untuk itu perlu suatu kajian lebih lanjut mengenai dinamika budaya sekolah ini.

\section{KESIMPULAN}

Berdasarkan hasil penelitian yang dilaksanakan, dapat disimpulkan bahwa gambaran dinamika budaya sekolah di MAN 2 Padangsidimpuan sudah bagus. Hanya saja penilaian untuk semua aspek budaya sekolah tersebut belum ada.

\section{UCAPAN TERIMAKASIH}

Terimakasih kepada Kemenristek Dikti melalui Simlitabmas dari DRPM DIKTI yang telah memberikan dana dalam penelitian ini untuk tahun 2019. 